Hasanuddin Economics and Business Review 04:3 (2021) 35-39

\title{
Promotion Strategy And Brand Loyalty: A Study Of Mobile Payment In South Sulawesi
}

\author{
Insany Fitri Nurqamar ${ }^{\mathrm{a}, *}$, Naufal Pratama Putra ${ }^{\mathrm{a}}$, Nurhayati $^{\mathrm{a}}$, Nihar Nurkhalifa $^{\mathrm{a}}$ \\ ${ }^{a}$ Management Department, Economic and Business Faculty, Hasanuddin University, Makassar, Indonesia
}

\begin{abstract}
Fintech or Financial Technology is an innovation that comes from digitizing management in the financial sector. Fintech is popularly used by millennials as a cash payment replacement tool. The purposes of this research are to determine and analyze the effect of promotional strategies used on brand loyalty. The respondents of this research were 140 millennial mobile payment users, specifically OVO, LinkAja, and Gopay which were randomly selected by using the proportional random sampling method. The data collection techniques used literature study and field study. It will be analyzed by using multiple regression methods. The results of the research have demonstrated that the promotion strategy affects positively and significantly toward brand loyalty of mobile payment OVO, Gopay, and LinkAja
\end{abstract}

Keywords: fintech, promotion, brand loyalty

\section{INTRODUCTION}

In the globalization era, the growth and development of technology have an important and significant role in the world. One of the products of this development is internet development. According to Your Dictionary, the internet substance is about communication between people around the world through electronic communication networks that are made possible because of computer network connectivity. Based on the data, it shows that the development of internet users in Indonesia is very significant.

Data Table 1 (internetworldstats, 2019) shows the significant development of internet users in Indonesia from year to year. Until 2019, the number of users reached 171,260,000 out of 269,536,482 populations. Communication relations and data exchange occur all the time, this interaction then leads to innovation to divert the real world to the internet. This is an impetus for business people (producers, distributors, traders) to make buying and selling transactions on the internet, or nowadays it is called online business. (Kartika Dewi and Kusumawati, 2018).

Following the development of online businesses, there are innovations by making digital payments or it can be called Financial Technology (Fintech). The National Digital Research Centre (NDRC) defined financial technology as an "innovation

\footnotetext{
* Author in correspondence,

Email address: insanyfitri@gmail.com (Insany Fitri Nurqamar)
}

ISSN: 2549-3221 (Print) 2549-323X (Online)

DOI: $10.26487 /$ hebr.v4i3.2576 in financial services". There are three types of financial technology. Firstly, Third-party payment systems, such as onlineto-offline $(\mathrm{O} 2 \mathrm{O})$ systems, cross-border, mobile payments, and payments platforms that provide Bank Transfer. Secondly, Peerto-Peer (P2P) Lending, which provides the lender and the borrower to meet through the internet. Thirdly, Crowdfunding, where the design, program, and content are published to the public and people send financial support for those creative works.

Santi et al. (2017) states that financial transactions through Fintech include payments, investments, borrowing money, transfers, financial plans, and comparison of financial products. The cashless transaction habit or non-cash, has also begun to be transmitted to consumers in rural areas and small to medium scale businesses. In that case, it has helped to encourage the growth of mobile payment services. IPrice's latest research in 2019 (Devita, 2019) states that mobile payment services are more popular with the increase in smartphones utilization by up to $70 \%$ in the last 5 years in Indonesia. Moreover, there are more choices of e-wallet applications or cardless digital wallets for transactions. Based on the data from Bank Indonesia, 38 e-wallet services have received official licenses. In 2018, Idris (2019) reported about e-wallet transactions in Indonesia that have reached USD 1.5 billion and are predicted to increase to USD 25 billion in 2023.

Quoting the article from Rachmatunisa (2019), based on data from the 2nd quarter of App Annie in 2019, the top 3 ewallet applications with the most monthly active users are still occupied by local users, such as Gopay, OVO, and LinkAja. Gopay is an e-wallet application from Gojek which the first decacorn startup with the most used by Indonesian users. Then 
Table 1: Internet user data

\begin{tabular}{rrrrcc}
\hline \multicolumn{6}{c}{ Table 1: Internet user data } \\
\hline Year & \multicolumn{1}{c}{ User } & Population & \% Pen. & GDP pc & Usage Source \\
\hline 2000 & $2,000,000$ & $206,264,595$ & $1.0 \%$ & The US \$ 570 & THAT \\
2007 & $20,000,000$ & $224,481,720$ & $8.9 \%$ & $\$ 1,916$ & THAT \\
2008 & $25,000,000$ & $237,512,355$ & $10.5 \%$ & 2238 & APJII \\
2010 & $30,000,000$ & $240,271,522$ & $12.5 \%$ & 2329 & THAT \\
2016 & $30,000,000$ & $242,968,324$ & $12.3 \%$ & 2858 & THAT \\
2019 & $17,000,000$ & $258,316,051$ & $34.1 \%$ & 3690 & APJII \\
\hline
\end{tabular}

Source:www.internetworldstats.com (2019)

OVO, which collaborated with Indonesian unicorn e-commerce, namely Tokopedia and LionAir, was able to make progress in increasing users significantly and experiencing an increase in monthly users in the first quarter of 2018 beating LinkAja. However, LinkAja is an e-wallet application for various state-owned enterprises (BUMN), namely T-Cash owned by Telkomsel, Mandir e-Cash owned by Bank Mandiri, UnikQu owned by Bank BNI, Telkom's T-money, and BRI's T-Bank continue to expand in the world of e-wallets. This can be seen through IPrice's research which shows LinkAja remaining in third place from the second quarter of 2018 to the first quarter of 2019.

The development of Fintech or start-up companies in Indonesia is getting stronger. Indonesia is one of the biggest online markets worldwide, with over 185 million internet users. This is an advantage of Fintech, which is carrying out the transactions online. Ease of utilizing service and service data access to make transactions anytime and anywhere is also one of the attractiveness that is offered by Fintech. Furthermore, the consumers could not resist the promotional strategies deals, such as cashback, discount, and voucher.

Citing ? article about consumer behavior in transacting with digital payment applications by looking at the research data conducted by an application-based research institute, Snap chart, there are three types of transactions that are most often used electronic money in digital wallets, namely retail transactions (28\%), online transportation orders (27\%), and online food orders $(20 \%)$. The rest is for e-commerce transactions $(15 \%)$ and bill payments (7\%). This data shows the use of electronic money for transportation, fast food ordering, and ecommerce among Indonesian consumers is becoming more popular. Consumers enjoy a transaction experience that is more practical, fast, safe, and certainly not complicated waiting for change.

Seeing the increasing interest in e-wallets encourages marketers to carry out sales promotions by utilizing digital marketing. Digital promotion is the data usages and electronic applications for planning and implementing concepts, distribution, promotion, and pricing to create exchanges that satisfy individual and organizational goals (Strauss and Raymond, 2001). The usual promotional activities are cashback, discounts, vouchers, promo codes/coupons, and many more. This has an impact on creating brand loyalty to consumers.

Citing IPrice's research on the best e-wallets in the world
(Devita, 2019), the most popular promotions are discounts, points, and cashback. In the form of collaboration with stores to reach remote areas, the e-wallet application uses QR pay or Quick Response Code (QRC) as one of the payment options issued by the Indonesian government in May 2019. Payment via QR Code is also used as a solution for card replacement payment methods for 65 million MSMEs (Micro, Small, and Medium Enterprises) in Indonesia.

Aaker (1991) stated that brand loyalty is a key consideration when playing a value on a brand that is to be bought or sold because a high customer base can be expected to generate a very predictable sales and profit stream. Several factors affect brand loyalty, namely the quality of the product, the design, the brand name, the store environment, the service quality, the promotion, and the price. The loyal customer will make regular repeat purchases, purchase across product and service lines, refers the product to others, and demonstrates an immunity to the full of competition (Griffin, 2010).

Based on the phenomenons, this research aims to examine the effect of promotional strategies on consumer loyalty in using digital payment methods (OVO, LinkAja, and Gopay) and what promotional strategies have had the most dominant influence on consumer loyalty in using digital payment methods (OVO, LinkAja, and Gopay).

\section{METHODS}

This research will be conducted for 1 (one) year and located in the city of Makassar by examining brand loyalty and the variables that affect the promotion strategy. This research is quantitative research by using the descriptive-verification method. The sample of this research is 140 mobile payment users (Gopay, OVO, and LinkAja) who belong to the millennial generation in South Sulawesi. The research sample was selected by using a proportional random sampling method. The data were collected using a questionnaire with a Likert scale. The method used to analyze the data in this research is regression analysis.

$$
Y=a+b_{1} X_{1}+b_{2} X_{2}+b_{3} X_{3}+b_{4} X_{4}+\mu
$$

Variable Promotional Strategies are measured by assessed respondent perceptions about the cashback, the gift, the discount, and the voucher (Kotler, 2018) that are offered by the 
mobile payment company. Variable Brand Loyalty is measured by respondent perceptions about cognitive loyalty, affective loyalty, conative loyalty, and action loyalty (Oliver, 2014), repeat purchases, refers to others, and competitor effect (Griffin, 2010).

\section{RESULTS}

Based on Table 2, the multiple regression analysis equations can be formulated, namely:

- OVO's brand loyalty $=5.401+0.693$ (cashback) +1.206 (discount) +0.347 (voucher) +1.383 (gift)

- Gopay's brand loyalty $=12,107+1,543$ (cashback) + 0.393 (discount) +1.398 (voucher) -0.131 (gift)

- LinkAja's brand loyalty = 7,767 - 0,156 (cashback) + 2,263 (discount) $+0,272$ (voucher) $+0,948$ (gift)

Based on Table 3 the T-test shows that:

1. The significance values for OVO, Gopay, LinkAja cashback are respectively $0.045 ., 0.019$., and 0.892. It shows the significant value of OVO and Gopay of 0.045 and $0.019<0.05$, so this shows that the data is significant. The data is not significant, because LinkAja's significance value is $0.892>0.05$.

2. The significance values for the OVO, Gopay, LinkAja discounts are respectively $0.004,0.707$, and 0.028 . It shows the significant value of OVO and LinkAja of 0.004 and $0.028<0.05$, so this shows that the data is significant. Meanwhile, the Gopay significance value is $0.707>0.05$, so the data is not significant.

3. The significance values on the OVO, Gopay, LinkAja vouchers are $0.378,0.146$, and 0.784 , respectively. It shows the significant value of OVO, Gopay, and LinkAja of 0.378., 0.146., 0.784>0.05. The result of the data is not significant.

4. The significance values for the OVO, Gopay, LinkAja gifts are $0.000,0.045$, and 0.234 , respectively. It shows the significant value of OVO and Gopay of 0.000 and $0.045<0.05$, so this shows that the data is significant. However, the LinkAja significance value is $0.234>0.05$, so the data is not significant.

Based on Table 4 the Anova test shows that:

1. OVO shows an $\mathrm{F}$ value of 53.147 with a significant value of $0.000<0.05$, which explains that the data is significant.

2. Gopay shows an $F$ value of 6.356 with a significant value of $0.001<0.05$, so the data is significant.

3. OVO shows an $\mathrm{F}$ value of 9.071 with a significant value of $0.000<0.05$ that explains the data is significant.

Based on Table 5, the coefficient of determination test shows that:
1. In OVO, the R Square value is obtained of 0.722 with a percentage value of $72.2 \%$ so that the regression value or the magnitude of the variance of OVO's brand loyalty which can be explained by cashback, discount, vouchers, and gifts simultaneously is $72.2 \%$.

2. In Gopay, the $\mathrm{R}$ Square value is obtained of 0.494 with a percentage value of $49.4 \%$ so that the regression value or the amount of the variance of Gopay's brand loyalty which can be explained by cashback, discount, voucher, and gifts simultaneously is $49.4 \%$.

3. In LinkAja, the R Square value is 0.681 with a percentage value of $68.1 \%$, so that the regression value or the amount of the variance of LinkAja's brand loyalty can be explained by cashback, discount, vouchers, and gifts simultaneously is $68.1 \%$.

\section{DISCUSSION}

Based on the test results, it is found that simultaneously promotional strategies, namely cashback, vouchers, discounts, and gifts affect brand loyalty. This applies to all research objects, both OVO, Gopay, and LinkAja. This proof can be seen from the results of the $\mathrm{F}$ test which tests the effect and significance of the independent variable on the dependent variable of the research. In most cases, based on the practical point of view, this affects because mobile payments have burnt money or massive promotions to gain market position and brand loyalty. This is based on many theories that promotions can influence buying decisions to form brand loyalty.

In the research object, OVO's promotional strategies have a significant effect on brand loyalty. Promotions that are boosted by OVO make the promotions influence brand loyalty. OVO has offered many promotions, especially cashback and discounts. Many merchants display OVO promotions in front of their stores so that consumers can find out about promotions from OVO directly. OVO also has an advantage because it carries out promotional gifts through OVO Points that many consumers like. The results of the R2 test show that promotions which include cashback, vouchers, discounts, and gifts have a simultaneous effect on the brand loyalty variable. This research shows that $72.2 \%$ of promotions can explain brand loyalty, while $27.8 \%$ can be explained by other variables that were not included in this study. This is under the opinion of Solomon et al. (2016) that sales promotions are carried out to prevent a decrease in brand loyalty. This happens because consumers tend to buy products based on cost, value, or convenience. Thus, special sales promotion offers are more likely to cause price-conscious customers to switch brands that are expected to use them over the long term.

In Gopay's research object, promotional strategies have a significant effect on brand loyalty. Frequent and varied promotions make Gopay popular with many consumers. Frequent promotions are discounts and cashback. The full information about promotions provided by Gopay also encourages Gopay to be widely used. Gopay also offers promos at well-known 
Table 2: The Results of Multiple Linear Regression Analysis

\begin{tabular}{cccccccc}
\hline & & Constant & Cashback & Discount & Vouchers & Gift \\
\hline \multirow{5}{*}{ Unstandardized Coeffcients } & & OVO & 5,401 & 0.693 & 1,206 & 0.347 & 1,383 \\
& & Gopay & 12,107 & 1,543 & 0.393 & 1,398 & -0.131 \\
& & LinkAja & 7,767 & -0.156 & 2,263 & 0.272 & 1,171 \\
& \multirow{3}{*}{ Std. Error } & OVO & 5,443 & 0.341 & 0.407 & 0.391 & 0.256 \\
& & Gopay & 13,217 & 0.617 & 1,034 & 0.932 & 0.765 \\
& & LinkAja & 13,535 & 1,130 & 0.945 & 0.976 & 0.948 \\
Standardized Coeffcients & & OVO & & 0.176 & 0.285 & 0.093 & 0.448 \\
& \multirow{3}{*}{ Beta } & Gopay & & 0.426 & 0.091 & 0.335 & -0.039 \\
& & LinkAja & & -0.032 & 0.529 & 0.079 & 0.358 \\
\hline
\end{tabular}

Table 3: T-test Summary

\begin{tabular}{|c|c|c|c|c|c|c|}
\hline & & Constant & Cashback & Discount & Voucher & Gift \\
\hline \multirow{3}{*}{$\mathrm{t}$} & OVO & 0,992 & 2,034 & 2,959 & 0,887 & 5,394 \\
\hline & Gopay & 0,916 & 2,499 & 0,380 & 1,500 & $-0,172$ \\
\hline & LinkAja & 0,574 & $-1,138$ & 2,394 & 0,279 & 1,235 \\
\hline \multirow{3}{*}{ Significance } & OVO & 0,324 & 0,045 & 0,004 & 0,378 & 0,000 \\
\hline & Gopay & 0,368 & 0,019 & 0,707 & 0,146 & 0,146 \\
\hline & LinkAja & 0,574 & 0,892 & 0,028 & 0,784 & 0,234 \\
\hline
\end{tabular}

Table 4: Analysis of Variance Test (Anova Test)

\begin{tabular}{ccccccc}
\hline & & Constant & Cashback & Discount & Vouchers & Gift \\
\hline \multirow{4}{*}{$\mathrm{t}$} & OVO & 0.992 & 2,034 & 2,959 & 0.887 & 5,394 \\
& Gopay & 0.916 & 2,409 & 0.380 & 1,500 & 0.172 \\
& LinkAja & 0.574 & 0.138 & 2,394 & 0.279 & 1,235 \\
\multirow{5}{*}{ Significance } & OVO & 0.324 & 0.045 & 0.004 & 0.378 & 0,000 \\
& Gopay & 0.368 & 0.019 & 0.707 & 0.146 & 0.146 \\
& LinkAja & 0.574 & 0.892 & 0.028 & 0.784 & 0.234 \\
\hline Model & & & $\mathbf{F}$ & Sig & Information \\
\hline OVO & Regression & 53,147 & 0,000 & Significant \\
Gopay & Regression & 6,356 & 0.001 & Significant \\
LinkAja & Regression & 9,071 & 0,000 & Significant \\
\hline
\end{tabular}

Table 5: Model Summary

\begin{tabular}{lcccc}
\hline Model & R & R Square & Adjust R Square & $\begin{array}{c}\text { Std. An error } \\
\text { of the Estimate }\end{array}$ \\
\hline OVO & 0.849 & 0.722 & 0.708 & 7,330 \\
Gopay & 0.703 & 0.494 & 0.417 & 10,180 \\
LinkAja & 0.825 & 0.681 & 0.606 & 8,738 \\
\hline
\end{tabular}


and favorite merchants for its users. The use of promos on Gopay also has no usage limit for one promo period. This encourages promotion to affect brand loyalty. The results of the R2 test explain that promotions that include cashback, vouchers, discounts, and gifts have a simultaneous effect on the brand loyalty variable, which in this research shows that $49.4 \%$ of promotions can explain brand loyalty. Meanwhile, 50,6\% can be explained by other variables not included in this study. This is following the opinion of Kotler (2018), in most cases, sales promotion should be used to strengthen positions and build relationships with users, not only for short-term sales or as a temporary brand switching. Sales promotions have the potential to build short-term excitement and long-term customer engagement and relationships.

In the research object of LinkAja, promotional strategies have a significant effect on brand loyalty. LinkAja has a theme in the form of "Bebas Tanpa Tunai" which means the users can make various kinds of payments without having to make cash payments, as well as offering promotions in the form of cashback to LinkAja users. LinkAja is also an e-wallet that offers benefits to its users by providing various features offered in its application with many attractive promos. Some are valid for several months, some are throughout the year. Examples of promos such as free data packages for certain types of transactions, administrative fee discounts, and cashback to free food delivery costs. The results of the R2 test define the promotions that include cashback, vouchers, discounts, and gifts that have a simultaneous effect on the variable brand loyalty which in this research shows that $68.1 \%$ of promotions can explain brand loyalty. Meanwhile, $31.9 \%$ can be explained by other variables not included in this research. This is under the opinion of (Grewal and Levy, 2018) that sales promotion has become an integral component of companies in the long-term Customer Relationship Management (CRM) program that is used to build customer loyalty.

\section{CONCLUSION}

Based on the results of the analysis of the Promotion Strategy Model in Mobile Payment to Brand loyalty, it can be concluded that the promotional strategy (cashback, discount, voucher, gift) simultaneously has a positive and significant effect on consumer loyalty of OVO, Gopay, and LinkAja. The promotional strategy in the form of discounts has the most dominant influence on consumer loyalty of OVO, Gopay, LinkAja.

\section{References}

Aaker, D. A., 1991. Managing brand equity: Capitalizing on the value of a brand name.

URL: https://www.inovaconsulting.com.br/wp-content/ uploads/2016/09/managing-brand-equity-by-david-aaker.pdf

Devita, V. D., 2019. Siapa Aplikasi E-wallet dengan Pengguna Terbanyak di Indonesia?

URL: https://iprice.co.id/trend/insights/ e-wallet-terbaik-di-indonesia/

Grewal, D., Levy, M., 2018. Marketing, 6th Edición. McGraw-Hill Education. URL: https://www.mheducation.com/highered/product/ m-marketing-grewal-levy/M9781259924033.html

Griffin, J., 2010. Customer loyalty: How to earn it, how to keep it. URL: https : //www . amazon . com/Customer-Loyalty-How-EarnKeep-ebook/

Idriłp/BD,12(\$1/X5Riset Ini Ungkap Aplikasi Pembayaran Digital Favorit Konsumen.

URL: https://inet.detik. com/cyberlife/d-4629663/risetini-ungkap-aplikasi-pembayaran-digital-favorit-konsumen

internetworldstats, 2019. Pengguna internet di indonesia.

URL: www . internetworldstats . com

Kartika Dewi, I., Kusumawati, A., 03 2018. Pengaruh Diskon Terhadap Keputusan Pembelian dan Kepuasan Pelanggan Bisnis Online (Survei Pada Mahasiswa Fakultas Ilmu Administrasi Universitas Brawijaya Angkatan 2013/2014 Konsumen Traveloka. Jurnal Administrasi Bisnis 56 (1), 155163 .

URL: http://administrasibisnis.studentjournal.ub.ac.id/ index.php/jab/article/view/2333

Kotler, Philip dan Armstrong, G., 2018. Principles of Marketing, 17th Edición. Pearson Education Limited.

URL: https : //www . pearson.com/nl/en_NL/

higher-education/subject-catalogue/marketing/Principlesof-Marketing-Kotler-Armstrong.html

Oliver, R. L., 2014. Satisfaction: A Behavioral Perspective on the Consumer: A Behavioral Perspective on the Consumer (2nd ed.). Routledge, New York. URL: doi .org/10.4324/9781315700892

DOI: https ://doi.org/10.4324/9781315700892

Rachmatunisa, 2019. 10 Fakta Persaingan GoPay, Ovo, Linkaja, dan Dana. URL: https://inet.detik.com/business/d-4666061/ 10-fakta-persaingan-gopay-ovo-linkaja-dan-dana-cs

Santi, E., Budiharto, B., Saptono, H., 2017. Pengawasan otoritas jasa keuangan terhadap financial technology ( peraturan otoritas jasa keuangan nomor 77/pojk.01/2016). Diponegoro Law Journal 6 (3), 1-20.

Solomon, M. R., Marshall, G. W., Stuart, E. W., 2016. Marketing: Real People, Real Choices, 8th Edition. Pearson.

URL: http: //www.pearsonhighered.com/solomon-8e-info/

Strauss, J., Raymond, F., 2001. E-marketing, 2nd Edición. Englewood Cliffs: Prentice Hall.

URL: https : //www . amazon. com/Marketing-Third-Judy-Strauss/ $\mathrm{dp} / 0130497576$ 